\title{
Integrating Multiple Solid Oxide Fuel Cell Modules*
}

$\begin{array}{ccccc}\begin{array}{c}\text { Burak Ozpineci } \\ \text { burak@ieee.org }\end{array} & \begin{array}{c}\text { Zhong Du } \\ \text { zdu1@utk.edu }\end{array} & \begin{array}{c}\text { Leon M. Tolbert } \\ \text { tolbert@utk.edu }\end{array} & \begin{array}{c}\text { Donald J. Adams } \\ \text { adamsdj@ornl.gov }\end{array} & \begin{array}{c}\text { Donald Collins } \\ { }^{3}\end{array} \\ \begin{array}{c}\text { donald.collins@netl.doe.gov } \\ \text { Oak Ridge National Laboratory }\end{array} & \begin{array}{c}{ }^{2} \text { Department of Electrical and } \\ \text { P.O. Box 2009 }\end{array} & \begin{array}{c}{ }^{3} \text { National Energy Technology } \\ \text { Computer Engineering }\end{array} \\ \begin{array}{c}\text { Oak Ridge, TN 37831-6472 } \\ \text { The University of Tennessee } \\ \text { Knoxville, TN 37996-2100 }\end{array} & \begin{array}{c}\text { P.O. Box 880 } \\ \text { Morgantown, WV 26507-0880 }\end{array}\end{array}$

Abstract-According to SECA program guidelines, solid oxide fuel cells (SOFC) will be produced in the form of 3-10 kW modules for residential use. In addition to residential use, these modules can also be used in apartment buildings, hospitals, etc., where a higher power rating would be required. For example, a hospital might require a $250 \mathrm{~kW}$ power supply. To provide this power using the SOFC modules, 25 of the $10 \mathrm{~kW}$ modules would be required. These modules can be integrated in different configurations to yield the necessary power. This paper will show five different approaches for integrating numerous SOFC modules and will evaluate and compare each one with respect to cost, control complexity, ease of modularity, and fault tolerance.

\section{INTRODUCTION}

Human dependence on electricity is growing faster with time. Coal, oil, and other energy sources have been used to generate electricity for more than a century. Today, as conventional fossil energy supplies, such as oil, coal and natural gas, are rapidly depleting, new energy sources are required to replace them. $\mathrm{NO}_{\mathrm{x}}, \mathrm{CO}_{2}$, and $\mathrm{SO}_{2}$ pollution is a major concern. To overcome these problems, renewable energy sources must replace fossil energy sources $[1,2]$.

Fuel cell technology is one of the options for renewable energy sources. The electrical efficiency of a fuel cell can be greater than $70 \%$ in theory (the current technology is presently capable of reaching around $45 \%$ ). The cogeneration of electrical energy and heat improves the exploitation of primary energy. The products of the chemical reaction in fuel cells are $\mathrm{H}_{2} \mathrm{O}$ when $\mathrm{H}_{2}$ is used as fuel, and $\mathrm{CO}_{2}$ when $\mathrm{CO}$ is used as fuel; no pollutants like $\mathrm{SO}_{\mathrm{x}}$ or $\mathrm{NO}_{\mathrm{x}}$, are produced. Therefore, fuel cells are environmentally cleaner than traditional generators even though they still have an important level of greenhouse gas $\left(\mathrm{CO}_{2}\right)$ emission especially when $\mathrm{CO}$ is used as fuel.

Each fuel cell produces around $1.2 \mathrm{~V}$; therefore, several fuel cells are grouped together into a fuel cell stack to produce higher voltages. The U.S. Department of Energy's Solid-State Energy Conversion Alliance (SECA) program [3] is targeting solid oxide fuel cell (SOFC) modules in the 3-10 $\mathrm{kW}$ range to be made available for residential applications

\footnotetext{
* Prepared by the Oak Ridge National Laboratory, Oak Ridge, Tennessee 37831, managed by UT-Battelle for the U.S. Department of Energy under contract DE-AC05-00OR22725.

The submitted manuscript has been authored by a contractor of the U.S. Government under Contract No. DE-AC05-00OR22725. Accordingly, the U.S. Government retains a non-exclusive, royalty-free license to publish from the contribution, or allow others to do so, for U.S. Government purposes.
}

[4-6]. In addition to residential use, these modules can also be used in apartment buildings, hospitals, etc., where a higher power rating would be required. For example, a hospital might require a $250 \mathrm{~kW}$ power supply. To provide this power using the SOFC modules, 25 of the $10 \mathrm{~kW}$ modules would be required. These modules can be integrated in different configurations to yield the necessary power. This paper will show five different approaches for integrating numerous SOFC modules and will evaluate and compare each one with respect to cost, control complexity, ease of modularity, and fault tolerance.

\section{PossiBle CONFIGURATIONS}

To integrate numerous SOFC modules, five different approaches are proposed in this paper: series, dc distribution, hfac distribution, cascaded multilevel, and multilevel. Each of these configurations will be described in the following subsections.

\section{A. Series configuration}

The simplest way of integrating fuel cells is to connect them in series and connect the output to a power converter as shown in Figs. 1 and 2. To achieve the required power level, fuel cells can also be paralleled. Note that, when paralleling

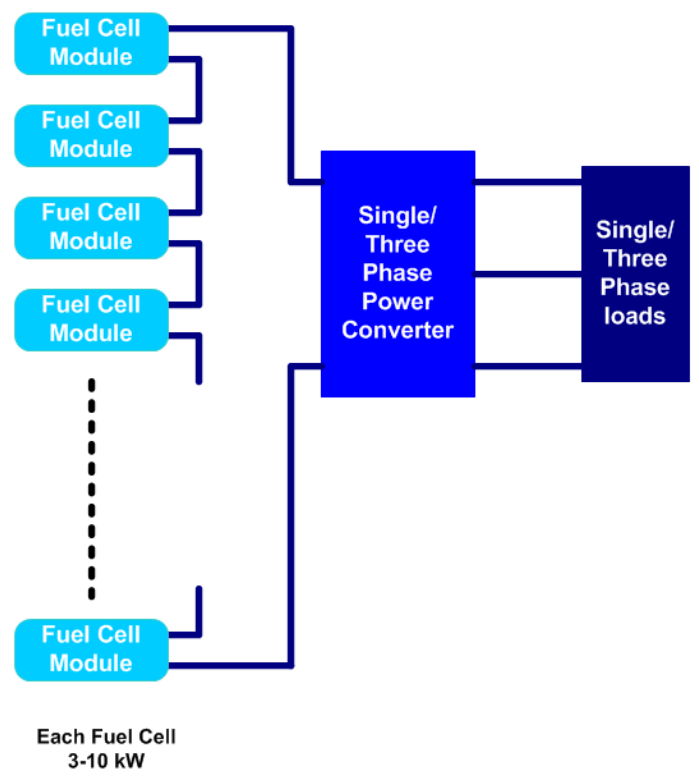

Fig. 1. Block diagram of the series configuration. 


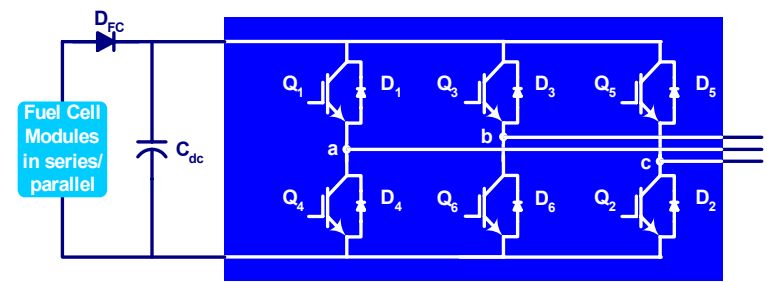

Fig. 2. Three-phase inverter.

fuel cells, extreme caution should be taken, since they cannot accept current; a diode should be inserted to block any possible circulating currents between the fuel cells.

The fuel cells in series are connected to a power converter through a dc-link (Fig. 2). This power converter is either a single-phase or three-phase inverter.

The fuel cell voltage decreases with increasing load current because of internal losses as shown in Fig 3; therefore, the dc-link voltage in Fig. 2 is not constant. In general operation, the inverter expects a constant dc-link voltage $\left(\mathrm{V}_{\mathrm{dc}}\right)$, but with voltage sensors on the dc-link and some modification on the inverter control system, it can also operate with variable dc-link voltage.

An alternative is to add a dc-dc voltage regulator to keep the dc-link voltage constant as in Fig. 4. This way the inverter input voltage will not be dependent on the load current.

The difference between these options is that in one of them, the inverter sees a constant dc voltage, while in the other one, the inverter sees the fuel cell voltage varying with the load current. Note that without a dc/dc converter the power switches have to be rated for higher voltages because at low loads the fuel cells will supply high voltages. When a $\mathrm{dc} / \mathrm{dc}$ converter is used, however, this is not a problem and the power switches can be rated at the required dc-link voltage.

There are some trade-offs between these two options. One of them is that without a dc/dc converter, the inverter switches have to be rated higher; therefore, the inverter will be more expensive. When a dc/dc converter is used, however, the inverter will have a lower rating and will be cheaper, but the dc/dc converter will add to the device count. The second trade-off concerns the control system. Without a

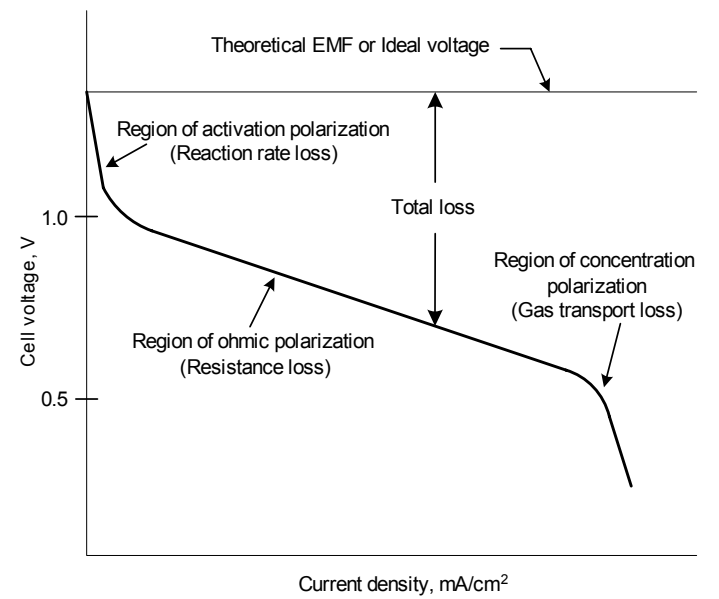

Fig. 3. Theoretical V-I polarization curve of a fuel cell.

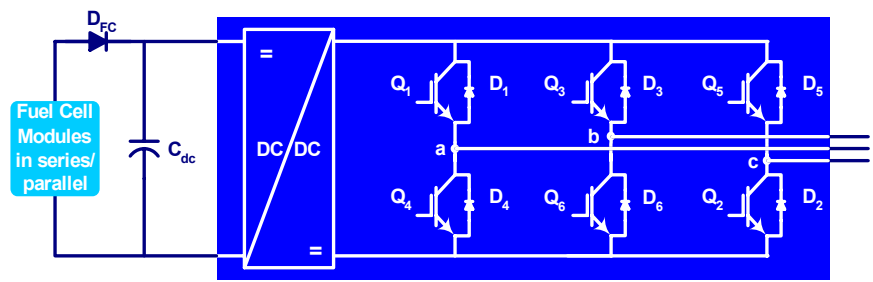

Fig. 4. Dc/dc voltage regulator and a three-phase inverter.

$\mathrm{dc} / \mathrm{dc}$ converter, the inverter control complexity increases, but the additional $\mathrm{dc} / \mathrm{dc}$ converter also adds to the control complexity.

The advantages of the series configuration are

- The fuel cell modules are connected in a simple series connection.

- Low device count. Only six power switches are required when no dc/dc regulator is used.

- Three-phase inverter modules are commonly used and because of this they are inexpensive. Note that higher voltage rated switches would be more expensive.

- This is a modular configuration consisting of fuel cell modules, an inverter module, and a $\mathrm{dc} / \mathrm{dc}$ converter module.

The disadvantages of the series configuration are

- If one fuel cell fails, the system will not work. The failing unit has to be replaced or bypassed externally. This causes reliability concerns.

- Fuel cell voltage and load are not controlled.

\section{B. DC distribution configuration}

To overcome the disadvantages of the series system, a step-up dc/dc converter can be connected to each fuel cell and the constant dc outputs of these converters can be connected in parallel producing the $\mathrm{dc}$ distribution configuration (Fig. 5).

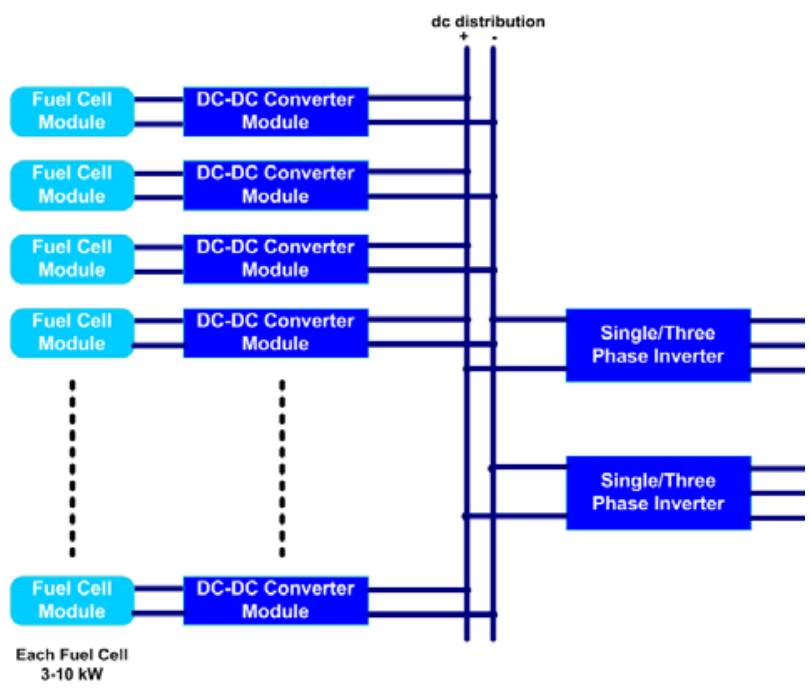

Fig. 5. Block diagram of the de distribution configuration. 
In this configuration, each fuel cell module has its own power converter module. These dc-dc converters most probably will have to be of boost type since the fuel cell module voltage typically is less than that of the dc distribution/link voltage.

To increase reliability, a redundant number of fuel cells can be connected in this configuration. Additionally, the constant voltage dc-link can also be used to feed one or several inverters depending on the application

The advantages of the dc distribution are

- Each fuel cell can be controlled independently with the dc-dc converter module. The fuel cell modules can even be disconnected from the system for maintenance or replacement and the rest of the system would continue the operation; therefore, this configuration is more reliable than the series connection.

- Increased reliability and fault tolerant operation can be achieved by adding redundant fuel cell modules together with dc-dc converter modules.

- Each subsystem can be designed as an individual module and combined together as needed. The list of modules would include: the fuel cell module, the dc-dc converter module, and the inverter module. The inverter is already commercially available in a module.

The disadvantages of the de distribution are

- When the instantaneous voltages at the outputs of the dc-dc converters are not equal, circulating currents will occur. These will interfere with the operation of the system; therefore, they have to be prevented.

- This configuration requires higher device count than the series configuration because of the dc-dc converters, but the devices have lower power ratings.

\section{High frequency ac (hfac) distribution configuration}

Each fuel cell is connected to an H-bridge inverter (Fig. 6), which converts the dc input to high frequency ac voltage typically at more than $20 \mathrm{kHz}$. This ac voltage most commonly can either be a sine wave, a square wave, or a square wave with zero intervals. It is fed to a high frequency transformer, which can boost the voltage if required. The secondary of this transformer is connected to one or several single-phase-to-three-phase cycloconverters or matrix converters, which convert the high frequency ac voltage to lower frequency ac voltage (like $60 \mathrm{~Hz}$ ).

The transformer brings the advantages of isolation, voltage boost, and the capability of adding other power sources and loads through a power converter. As seen in Fig. 6, several converters can be connected to the extra primary and secondary taps and the power can flow in different directions as required by the application.

This hfac transformer is much smaller than a typical bulky $60 \mathrm{~Hz}$ transformer. As the frequency increases the size of a transformer decreases. A $42 \mathrm{kVA} 20 \mathrm{kHz}$ transformer weighs

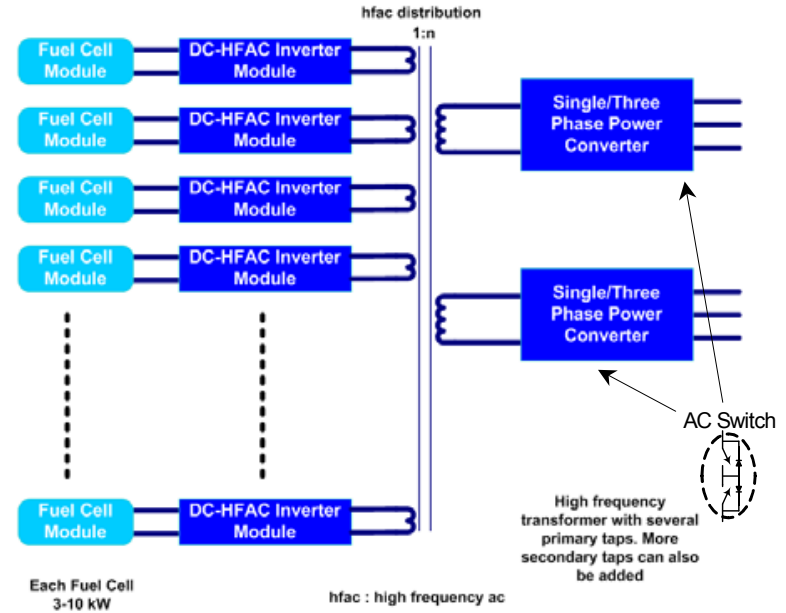

Fig. 6. Block diagram of the hfac distribution configuration.

just a few pounds and has dimensions of roughly a cube with $12 \mathrm{~cm}$ per side.

The problem of fuel cell voltage varying with load also exists for this configuration. One solution to this problem is to put extra voltage regulators at the fuel cell outputs. The other solution involves monitoring fuel cell voltages and modifying the control signals accordingly; however, if the cycloconverter/matrix converter uses Pulse Density Modulation (PDM), the problem would be solved without any additional hardware or software since the PDM control depends on the voltage-time area of the output.

The advantages of the hfac distribution are

- Because of the high frequency operation, the harmonics are at higher orders and it is easier to filter these with smaller filters.

- The passive components required at high frequencies are smaller just as in the case of the transformer.

- Modularity is similar to the de distribution case.

The disadvantages of the hfac distribution are

- The hfac transformer has to be specially designed; therefore, it will be expensive.

- If the transformer input voltage has a de component, there will be a problem of transformer saturation.

- Cycloconverters and matrix converters require ac switches, which are two switches connected back-toback as shown in Fig. 6. They are not commonly available as modules.

- The control is complex because of the cycloconverter/matrix converter control and their interaction with the single-phase high frequency inverters.

\section{Cascaded multilevel configuration}

Instead of connecting the fuel cell and the power converter pairs in parallel as in the de distribution case, they can be 


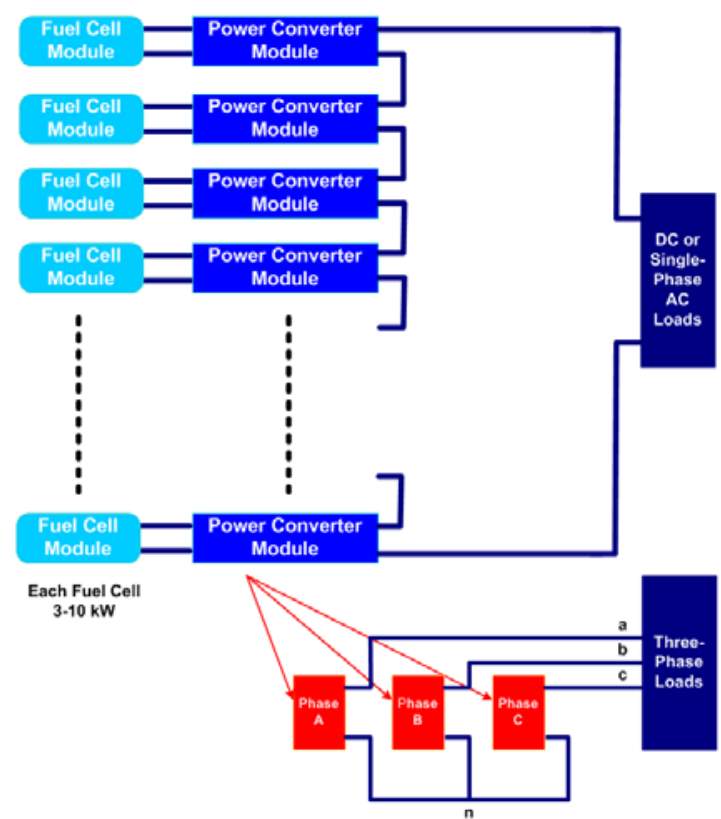

Fig. 7. Block diagram of the cascaded multilevel configuration.

connected in series to form a cascaded multilevel converter as shown in Fig. 7.

There are many multilevel converter configurations [7] available. Among these, cascaded multilevel converters are distinct in the sense that they are more modular than the rest, and the input sources are isolated from each other; that is why, in this paper, cascaded multilevel converters have been classified apart from regular multilevel converters.

Cascaded multilevel converters consist of a series connection of several fuel cell and power converter module pairs. If all the power converters are inverters, then the resulting system is a single-phase multilevel inverter. Three of these single-phase inverters can be connected in wye or delta to produce three-phase multilevel inverter systems. A seven-level cascaded multilevel inverter circuit diagram is shown in Fig. 8.

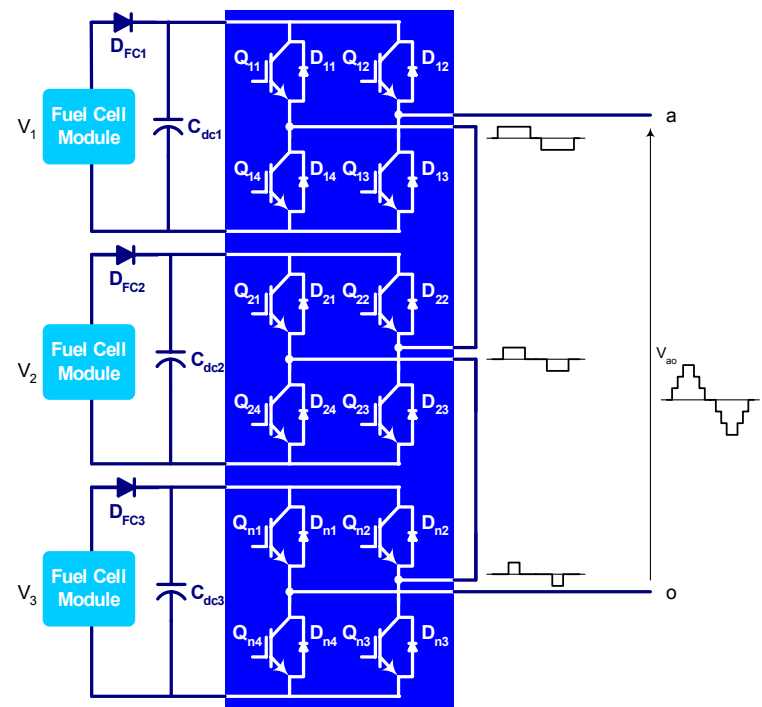

Fig. 8. One phase of a cascaded three-level inverter.

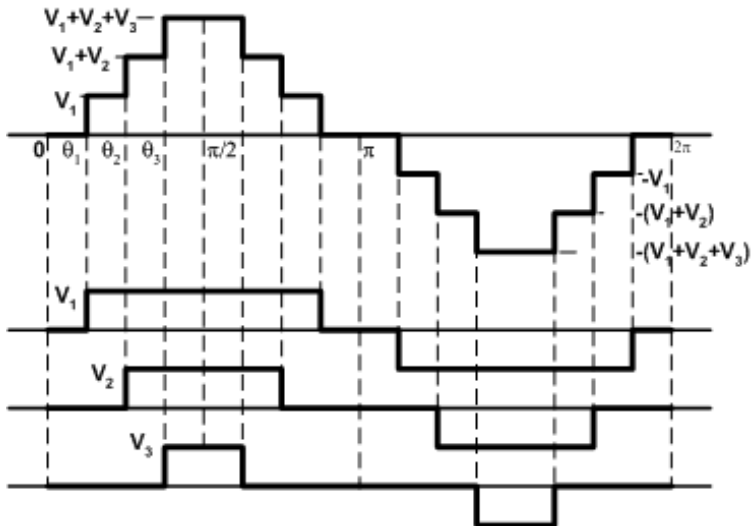

Fig. 9. Waveforms of a cascaded three-level inverter.

Each H-bridge converter produces a square wave with zero intervals at different duty ratios. At the output of the converter, these voltages are summed to get a stepped output voltage as shown in Figs. 8 and 9. Three of these singlephase voltages can be connected to form a three-phase supply as shown in Fig. 7.

The power converter module can also be a dc-dc converter, in which case the above configuration would be a multilevel dc-dc converter [8] and can be fed to either dc loads or three-phase inverters to produce three-phase ac voltages as shown in Fig. 10.

To overcome the fuel cell voltage drop, either voltage regulators have to be connected at the fuel cell outputs or fuel cell voltages have to be monitored and the control signals have to be modified accordingly.

The advantages and the disadvantages of cascaded multilevel converters will be listed in the next section.

\section{E. Multilevel configuration}

Fuel cell modules can be connected to one single/three

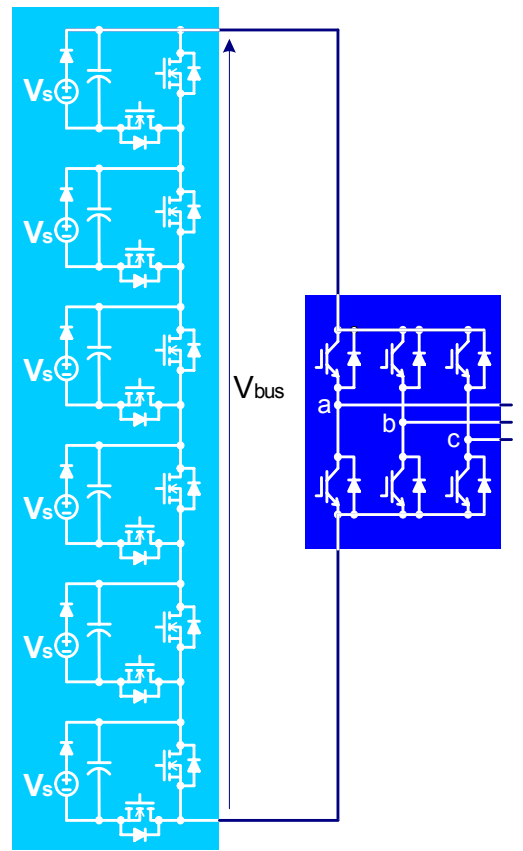

Fig. 10. 6-level dc-dc converter 


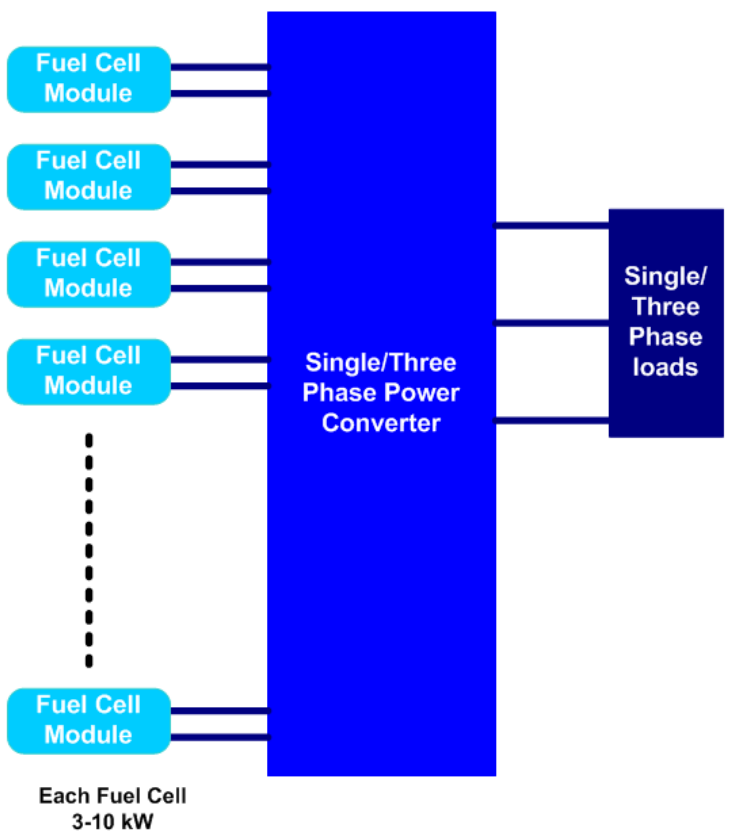

Fig. 11. Block diagram of the multilevel configuration.

phase multilevel inverter as shown in Fig. 11. In this case, there might not be a need for a voltage regulator if fuel cell voltages are monitored.

There are many types of multilevel inverters. One typical multilevel inverter, the diode clamped multilevel inverter is shown in Fig. 12 for four fuel cell modules.

The stepped output voltage waveform of a multilevel inverter is similar to the one in Fig. 9.

The advantages of multilevel converters are

- They are modular, lowering manufacturing costs. The cascaded multilevel converter is more modular than the other multilevel converters.

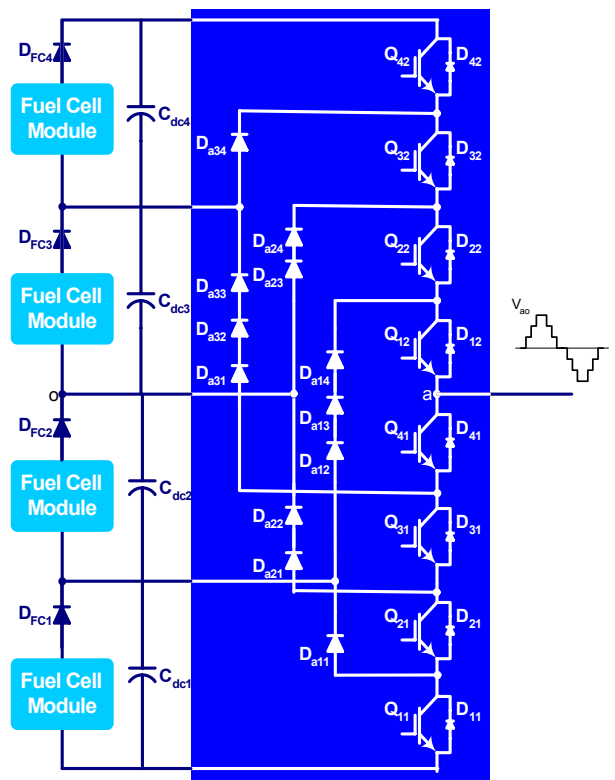

Fig. 12. One phase of a diode clamped three-level inverter.
- Redundant levels can be added for increased reliability.

- Since each phase is built separate from the others, the final converter can be easily connected to be singlephase, multi-phase, or three-phase wye or delta.

- Fundamental frequency switching technique $[9,10]$ can be applied to decrease the switching losses and to increase the converter efficiency

- Other control strategies such as multilevel PWM [11], multilevel space vector PWM, etc. are possible.

The disadvantages of multilevel converters are

- The number of devices used in multilevel converters is high but the voltage ratings of these devices are lower. Increased number of switches increases the price, but lower rated switches are inexpensive.

- Because of fundamental frequency switching, lower order harmonics are higher, but there are techniques to reduce these harmonics [9]. For example, the switching angles can be selected so that the required fundamental voltage is achieved with no 5th or 7th order harmonics. Total harmonic distortion (THD) of 3\% has been achieved with an efficiency of $98 \%$ for loads greater than $98 \%$ of its rated power using fundamental frequency switching.

- For fuel cell applications, ripple current must be avoided. For a multilevel converter, high ripple in the fuel cell current is present.

\section{CONCLUSIONS}

Five different configurations to integrate multiple SOFC modules were proposed in this paper. The advantages and the disadvantages of each configuration were stated in comparison with the other configurations. It must be noted that even though focus in this paper was on SOFC modules, the configurations presented can also be applied to other fuel cell modules.

\section{REFERENCES}

[1] C. A. Forbes, J. F. Pierre, "The solid fuel-cell future," IEEE Spectrum, 30(10), Oct. 1993, pp. 40-44.

[2] D. J. Hall, R. G. Colclaser, "Transient modeling and simulation of a tubular solid oxide fuel cell" IEEE Transactions on Energy Conversion, vol. 14, no. 3, Sept. 1999, pp. 749-753

[3] Solid State Energy Conversion Alliance webpage, http://www.seca.doe.gov/

[4] C. D. M. Oates, R. W Crookes, S. H Pyke, and R. T. Leah, "Power conditioning for solid oxide fuel cells," International Conference on Power Electronics, Machines, and Drives, 4-7 June 2002, pp. 12-17.

[5] K. W. E. Cheng, D. Sutanto, Y. L. Ho, K. K. Law, "Exploring the power conditioning system for fuel cell," IEEE Power Electronics Specialists Conference, 17-21 June 2001, pp. 2197-2202. 
[6] K. Sedghisigarchi, A. Feliachi, "Control of gridconnected fuel cell power plant for transient stability enhancement," IEEE Power Engineering Society Winter Meeting, 27-31 Jan. 2002, pp. 383-388.

[7] L. M. Tolbert, F. Z. Peng, "Multilevel converters as a utility interface for renewable energy systems," IEEE Power Engineering Society Summer Meeting, July 1520, 2000, Seattle, Washington, pp. 1271-1274.

[8] G. J. Su, "Multilevel DC link inverter," US patent no. $6,577,087$.

[9] J. N. Chiasson, L. M. Tolbert, K. J. McKenzie, Z. Du, "Control of a multilevel converter using resultant theory," IEEE Transactions on Control System Theory, vol. 11, no. 3, May 2003, pp. 345-354.

[10] L. M. Tolbert, J. N. Chiasson, K. J. McKenzie, Z. Du, "Control of cascaded multilevel converters with unequal voltage sources for HEV," IEEE International Electric Machines and Drives Conference, June 1-4, 2003, Madison, Wisconsin, pp. 663-669.

[11]L. M. Tolbert, F. Z. Peng, T. G. Habetler, "Multilevel PWM methods at low modulation indices," IEEE Transactions on Power Electronics, vol. 15, no. 3, July 2000, pp. 719-725. 